
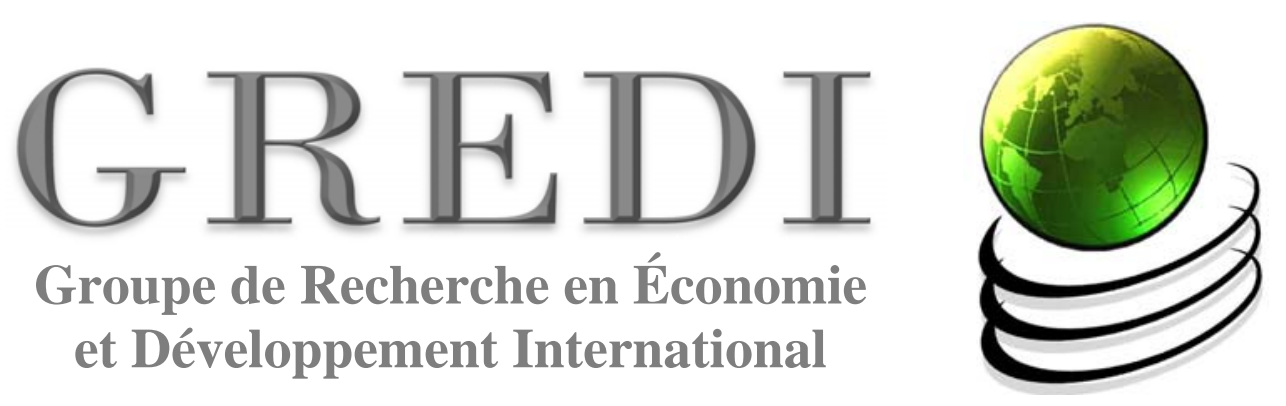

Cahier de Recherche / Working Paper

10-09

\title{
From a conventional to a sustainable engineering design process: different shades of sustainability
}

\author{
Bruno Gagnon \\ Roland Leduc \\ Luc Savard
}




\title{
From a conventional to a sustainable engineering design process: different shades of sustainability
}

Bruno Gagnon ${ }^{1}$; Roland Leduc ${ }^{2}$; and Luc Savard ${ }^{3}$

\begin{abstract}
The challenge of realigning the present path of development on a sustainable trajectory is shared among all sectors of society, including engineering. To move towards a more sustainable practice of engineering, the design process needs to be modified in order for engineers to tackle the related issues in a structured manner. Such "sustainable design processes” (SDPs) are proposed in the recent literature. By reviewing conventional as well as sustainable design processes, this paper aims to identify the major differences between the former and the latter. Critical tasks missing from SDPs proposed so far are also pointed out, according to key observations emerging from the field of sustainability science. These tasks are then combined with contributions from reviewed SDPs into a novel integrated sustainable engineering design process (ISEDP). Instead of representing conventional and sustainable engineering as a dichotomy, this paper rather places both approaches on a continuum along which the engineer or an organization can position itself. For this purpose, a procedure based on the IESDP is proposed, allowing one to assess its progress towards sustainable engineering. The method reveals different shades of sustainability along six dimensions: (1) the structure of the design process; (2) the scope of sustainability issues considered; (3) the relevance of the indicators guiding the design; (4) the accuracy of the tools used to evaluate the indicators; (5) the potential improvements expected from the alternatives assessed when compared to conventional solutions; and (6) the approach to decision making.
\end{abstract}

Subject headings: Sustainable development; Design; Engineering profession; Professional practice.

\footnotetext{
${ }^{1}$ Ph.D. Candidate, Dept of Civil Engineering, Université de Sherbrooke, Sherbrooke, QC, Canada, J1K 2R1 (corresponding author). E-mail: bruno.gagnon@usherbrooke.ca

${ }^{2}$ Professor, Dept of Civil Engineering, Université de Sherbrooke, Sherbrooke, QC, Canada, J1K 2R1. E-mail: roland.leduc@usherbrooke.ca

${ }^{3}$ Associate Professor. Dept of Economics, Université de Sherbrooke, Sherbrooke, QC, Canada, J1K 2R1.E-mail: luc.savard@usherbrooke.ca
} 


\section{Introduction}

With the publication of Our Common Future (WCED 1987), sustainable development emerged as a publicly recognized and well-defined concept. The need to realign the current path of development on a sustainable trajectory was already understood more than two decades ago. Recent events and observations remind us of the magnitude and the urgency of such a change: ever rising world carbon emissions (IPCC 2007), limited progress towards Millennium Development Goals (UN 2009), stagnating or declining life satisfaction in OECD countries (The Conference Board of Canada 2009), increasing number of threatened species (Vié et al. 2009), etc. This challenge calls for active contributions from individuals and organizations among all sectors of activity and from various fields of knowledge. Various initiatives spurred during the last decade, simultaneously addressing environmental protection, economic development and social equity, to constitute the foundations of what can be called a "Sustainability Revolution” (Edwards 2005). New approaches also appeared in the field of engineering, revolving around a redefinition and reorganization of the design process to better address sustainability issues. To understand the level of change in sustainable design processes (SDPs) proposed so far, more common or conventional approaches to engineering design are first presented. Afterwards, the modifications suggested in the reviewed SDPs are discussed according to key observations emerging from the field of sustainability science. This leads to the identification of further improvements, which are combined with modifications suggested previously into an integrated sustainable engineering design process (ISEDP). Finally, a novel procedure allowing engineers and organizations to evaluate their progress towards a more sustainable design process is proposed.

\section{Literature review of conventional design processes}

Design is one among many other tasks conferred to engineers such as: project and team management, operation and maintenance management, site supervision, quality control, research and development, etc. Nonetheless, it remains a central part of engineering practice as the design of specific objects or projects is often exclusively devoted to engineers. 
Before discussing the elaboration and dissemination of the sustainable design process, it is useful to define the characteristics of the actual, or conventional, design process commonly adopted by engineers. The phases and particularities of a variety of proposed design processes are reviewed in Table 1 to present a comprehensive overview of the conventional design process (CDP).

Table 1. Conventional design processes

\begin{tabular}{|c|c|}
\hline Reference & Main design phases and comments \\
\hline Dhillon (1996) & $\begin{array}{l}\text { (1) Problem identification. (2) Problem definition. (3) Information gathering. (4) Task } \\
\text { specifications. (5) Idea generation. (6) Conceptualization of the alternative solutions. } \\
\text { (7) Analysis of the alternative solutions according to the design specifications to } \\
\text { identify the optimum one. (8) Experimentation. (9) Solution presentation. (10) } \\
\text { Production. (11) Product distribution. (12) Consumption. }\end{array}$ \\
\hline Dym and Little (1999) & $\begin{array}{l}\text { (1) Problem definition: clarifying objectives, identifying constraints, establishing } \\
\text { functions. (2) Conceptual design: setting design specifications, generating alternatives. } \\
\text { (3) Preliminary design: modelling design, testing and evaluating design. (4) Detailed } \\
\text { design: refining and optimizing design. (5) Design communication: documenting } \\
\text { design. Every phase has clear inputs and outputs. Feedback loops are essential. }\end{array}$ \\
\hline Boucl & $\begin{array}{l}\text { (1) Initiation of project. (2) Generation of alternatives and definition of criteria. (3) } \\
\text { Analyses and evaluations of alternatives. (4) Final selection. The design is undertaken } \\
\text { by one or many organizations and different phases are placed under the responsibility } \\
\text { of different teams or individuals. The process is not sequential and incorporates } \\
\text { feedback loops. Some phases are done explicitly while others are realized in an implicit } \\
\text { manner. }\end{array}$ \\
\hline $\begin{array}{l}\text { Ordre des ingénieurs du } \\
\text { Québec }(2003)^{\mathrm{a}}\end{array}$ & $\begin{array}{l}\text { (1) Data identification: identifying the problem, the context and the constraints. (2) } \\
\text { Analysis: Generation and evaluation of alternatives, choice of a preferred alternative. } \\
\text { (3) Preliminary design: elaboration and communication of the chosen alternative. (4) } \\
\text { Detailed design: specific data gathering, detailed analysis, optimization and } \\
\text { communication. (5) Realization: provisioning, site supervision and follow-up. (6) } \\
\text { Operation: start-up, operation and maintenance. }\end{array}$ \\
\hline Mosb & $\begin{array}{l}\text { (1) Problem definition: clarifying the problem and identifying constraints. (2) } \\
\text { Information gathering. (3) Solutions generation. (4) Analysis and evaluation: using } \\
\text { tools to determine if solutions meet or exceed evaluation criteria. (5) Selection of the } \\
\text { best solution. (6) Communication and implementation of the solution. }\end{array}$ \\
\hline Mulder (2006) & $\begin{array}{l}\text { (1) Analysis: identifying and clarifying the design problem, defining the design goal, } \\
\text { defining functional and technical requirements. (2) Synthesis: generating and outlining } \\
\text { potential solutions. (3) Simulation: model the expected behaviour of the product. (4) } \\
\text { Evaluation: comparing simulation results with requirements. (5) Decision: confirming } \\
\text { the validity of the solution. The design process is iterative in nature. }\end{array}$ \\
\hline
\end{tabular}

${ }^{a}$ The Ordre des ingénieurs du Québec, unlike many other engineering organizations, gives a detailed description of the design process in its general guide to professional practice and was thus included in the review.

The phases defined in the CDPs of Table 1 show many similarities upon which we build to propose the generic conventional engineering design process in Table 2. The accompanying diagram (Figure 1) 
illustrates the iterative nature of the design process, as well as important decision points and data. The format adopted to represent the generic CDP is based on the structure elaborated by Bouchart et al. (2002).

Table 2. Generic CDP tasks

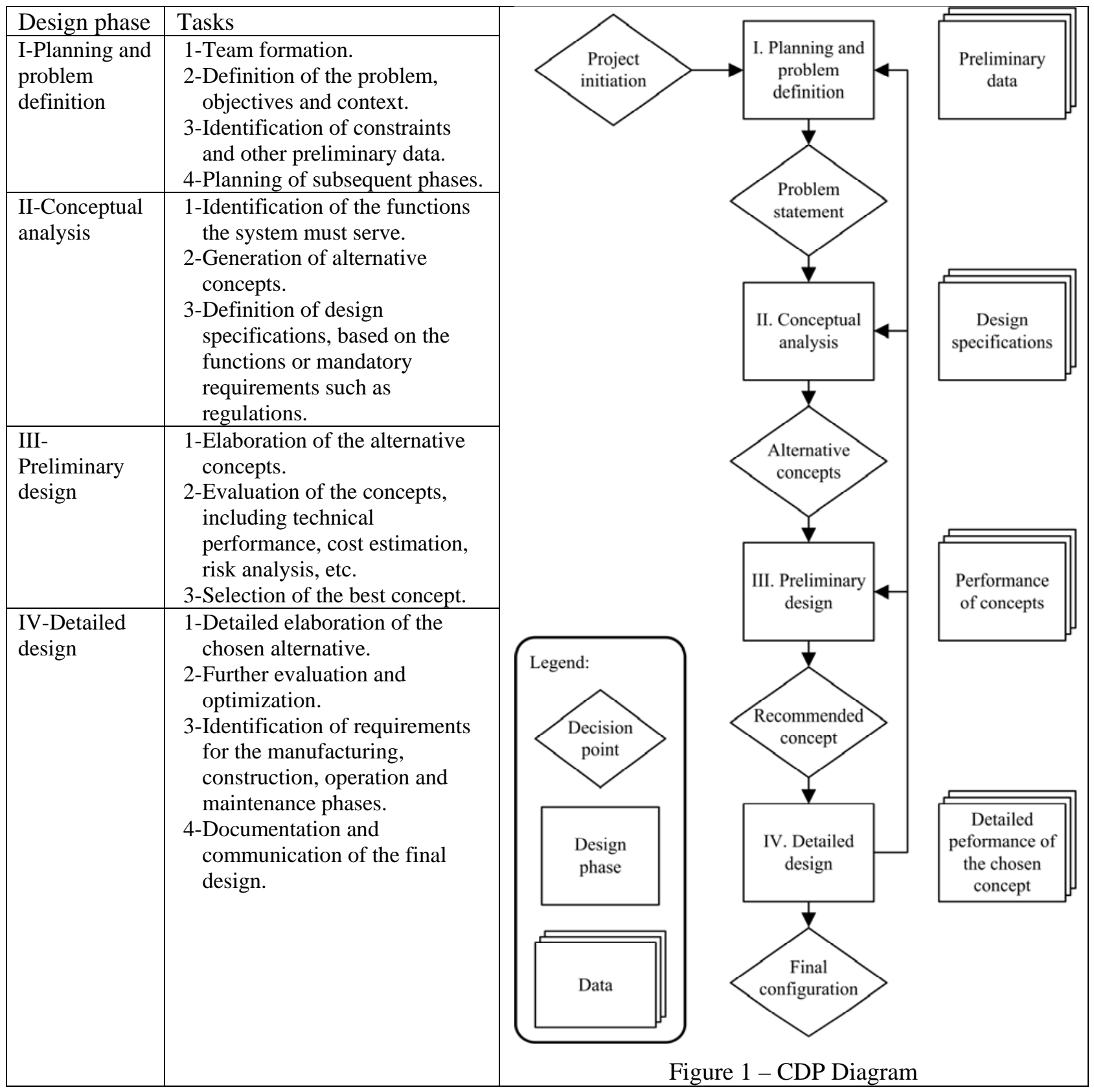

The most important difference existing between the CDPs reviewed consists in the inclusion or exclusion of phases following design, such as production and operation, in the design process. Undoubtedly, these 
phases must be considered during design and their monitoring in projects currently under way can hold valuable lessons for future projects. For clarity purposes, implementation and other subsequent phases were considered to be part of a project's life cycle, but not part of the design process itself. The complementarities between the design phases and the life cycle stages of a project are further discussed in the following sections on sustainable design.

One could legitimately ask whether "textbook" design processes such as those just reviewed are actually followed in practice. A recent study by Mosborg et al. (2005) showed that practicing engineers generally agree with the schematic representation made of the design process, while emphasizing its iterative nature as well as the importance of communication with partners involved.

Decision mapping of engineering projects in the water sector in the United Kingdom gave additional insight on the typical approach to decision making in CDPs (Ashley et al. 2008). The study showed that conventional engineering is concerned with a "relatively narrow set of economic and technical criteria, mainly related to costs, risk, environmental impact, and maintaining flexibility and build quality.”

In order to successfully implement the conventional design process, engineers can rely on a variety of tools such as: functional analysis, creativity methods, quality function deployment (QFD) matrixes, experiments, computer simulations, risk analysis, cost estimation, multi-criteria analysis, etc. Various constraints must also be considered: budget, schedule, regulations, codes, patents, organizational strategies, public policies, etc.

\section{Sustainable design process}

Mulder (2006) phrased how sustainable design deeply contrasts with conventional one: “[...] sustainability is not an add-on criterion. It is about all characteristics that a design should meet." Sustainability issues must thus be considered by engineers in all design phases of a project through well 
integrated complements to the conventional approach. Many SDPs have been proposed in recent years and the following tables highlight the main modifications proposed to transform the conventional design process into a sustainable one. The SDPs in Table 3 were developed exclusively for engineering design, while those in Table 4 concern decision making for a wider range of applications.

Table 3. Sustainable engineering design processes (letters in brackets refer to Table 7)

\begin{tabular}{|c|c|}
\hline Reference & oposed modifications to the conventional design process \\
\hline $\begin{array}{l}\text { [A] Byggeth } \\
\text { (2001) }\end{array}$ & $\begin{array}{l}\text { The method for sustainable product development (MSPD) is based on two central components of } \\
\text { the Natural Step framework: the four principles for sustainability (or system conditions) and } \\
\text { backcasting (or ABCD-analysis). At each phase of the design process (investigation of need, } \\
\text { product principles, primary product, production preparation and launch) conventional tasks are } \\
\text { complemented with a sustainability product analysis (SPA). SPA modules are constituted of } \\
\text { structured questions detailing the aforementioned principles. Solutions carried on to the } \\
\text { subsequent phases are selected along a prioritization matrix in order to fit in a long-term strategy } \\
\text { towards sustainability while being economically realistic. }\end{array}$ \\
\hline $\begin{array}{l}\text { [B] ISO } \\
(2002)\end{array}$ & $\begin{array}{l}\text { The ISO } 14062 \text { technical report describes how to integrate environmental aspects into product } \\
\text { design and development. Fundamental issues include the adoption of life cycle thinking and the } \\
\text { use of a multi-criteria approach to handle compromise between various environmental, economic, } \\
\text { social or technical issues. Additions to the design process mainly concern planning (definition of } \\
\text { environmental requirements and evaluation of a reference product), preliminary design } \\
\text { (environmental assessment of potential solutions, then comparison with targets and reference } \\
\text { product) and product launch (environmental communication). }\end{array}$ \\
\hline $\begin{array}{l}\text { [C] Lu and } \\
\text { Gu (2003) }\end{array}$ & $\begin{array}{l}\text { Sustainable product development simultaneously considers functional, environmental and } \\
\text { economic requirements. These are respectively evaluated through life cycle quality (LCQ), life } \\
\text { cycle assessment (LCA) and life cycle costing (LCC). Assessments are performed on a process } \\
\text { level and results are aggregated along four life cycle stages: extraction, production, operation and } \\
\text { retirement. Alternative solutions are finally compared according to their respective profiles. }\end{array}$ \\
\hline $\begin{array}{l}\text { [D] Cr } \\
\text { Diehl }\end{array}$ & $\begin{array}{l}\text { Design for sustainability (D4S) considers a number of issues linked to people, planet and profit. } \\
\text { Modifications are suggested along all design phases and include: (1) choosing team members } \\
\text { from with various expertises; (2) defining goals and objectives through the analysis of drivers } \\
\text { related to the three pillars of sustainability; ( } 3 \text { ) assessing the life cycle impact of a reference } \\
\text { product; (4) selecting strategies to guide idea generation; (5) assessing solutions according to } \\
\text { environmental, social and economic criteria; (6) sustainability communication; and (7) } \\
\text { sustainability performance monitoring after product launch. }\end{array}$ \\
\hline $\begin{array}{l}\text { [E] Ashley } \\
\text { al. (2008) }\end{array}$ & $\begin{array}{l}\text { The framework for sustainable decision support is one of the main outcomes of the Sustainable } \\
\text { water industry asset resource decisions (SWARD) project. The SWARD SDP emphasizes the } \\
\text { selection of appropriate sustainability criteria and indicators from four categories: economic, } \\
\text { environmental, social and technical. Other key elements comprise: (1) collection of data with } \\
\text { appropriate tools for all sustainability dimensions; (2) selection of the preferred option with multi- } \\
\text { criteria assessment; and (3) post-project monitoring with relevant criteria and indicators. }\end{array}$ \\
\hline
\end{tabular}

The terms principles, issues, criteria and indicators are mentioned in a majority of SDPs, without having exactly the same meaning from one reference to another. To ensure clarity, these terms are defined as follow, based on their typical use in the sustainability literature: 
- Principles are fundamental propositions which ensue from core values of sustainable development and serve to guide actions or conduct.

- Issues are aspects or characteristics of a given activity relating to one or many principles of sustainable development.

- Criteria are dimensions along which alternatives can be classified or ordered to facilitate assessment or decision making.

- Indicators are measurable parameters, quantitative or qualitative, serving to assess the performance of alternatives along their associated criteria.

Table 4. General approaches to sustainable decision-making (letters in brackets refer to Table 7)

\begin{tabular}{|c|c|}
\hline Reference & Proposed modifications to the conventional design process \\
\hline $\begin{array}{l}\text { [F] Weaver et } \\
\text { al. (2000) }\end{array}$ & $\begin{array}{l}\text { Backcasting is central to the SDP defined by the Dutch Sustainable technology development } \\
\text { programme. Backcasting consists in (1) a strategic problem definition outlining current or future } \\
\text { unsustainability associated with actual technologies; (2) defining a vision of how the needs under } \\
\text { study could be met sustainably in the long-term future ( } 50 \text { years from now), based on } \\
\text { sustainability principles; (3) working backward from the future vision to the present in order to } \\
\text { elaborate potential solution pathways; and (4) evaluating the different options to choose among } \\
\text { them. Sustainable solutions should, among other criteria, achieve a factor-10 to factor-50 } \\
\text { ecological footprint reduction, on a life cycle basis, when compared to the current solutions. }\end{array}$ \\
\hline $\begin{array}{l}\text { [G] Azapagic } \\
\text { and Perdan } \\
\text { (2005a) }\end{array}$ & $\begin{array}{l}\text { Authors propose an integrated sustainability decision-support framework structured along three } \\
\text { general phases: problem structuring, analysis and resolution. The identification and involvement } \\
\text { of stakeholders is the first and most important step as they play a significant role in all subsequent } \\
\text { steps. Other important complements to problem structuring include the identification of key } \\
\text { sustainability issues and indicators, as well as the choice of a multiple criteria decision analysis } \\
\text { (MCDA) approach. Problem analysis mainly consists in the evaluation of alternatives and their } \\
\text { comparison with the chosen MCDA approach. Finally, the most sustainable alternative is chosen } \\
\text { and implemented during the problem resolution phase. }\end{array}$ \\
\hline $\begin{array}{l}\text { [H] Boyko } \\
(2009)\end{array}$ & $\begin{array}{l}\text { The sustainable urban design decision-making process, developed in the VivaCity2020 Project, } \\
\text { improves the conventional design process by integrating "sustainability tasks" and "sustainability } \\
\text { reviews" along all design phases. Main sustainability tasks consist in: (1) identifying and } \\
\text { prioritizing of sustainability issues constituting a "sustainability agenda"; (2) developing } \\
\text { sustainability advice on preliminary designs using relevant tools and highlighting tradeoffs } \\
\text { between sustainability issues; (3) assessing the performance of the design against the } \\
\text { sustainability agenda; (4) developing a strategy for sustainability monitoring. Sustainability } \\
\text { reviews are checkpoints between phases to ensure sustainability tasks are conducted in a } \\
\text { satisfying manner. }\end{array}$ \\
\hline
\end{tabular}

Most reviewed SDPs emphasize the importance of using appropriate tools, especially for the analysis of potential solutions and the synthesis of the data gathered. Sustainability tools relevant for engineering design are cited in the reviewed SDPs, as well as other references (Robèrt et al. 2002; Ness et al. 2007), 
and are listed in Table 5. Key creativity tools emerging in the field of sustainability, which often receive less attention than analysis and synthesis tools, are also listed. Their role in the design process will be discussed in the next sections. Note that stakeholder participation is not present in Table 5 because it encompasses all categories. Depending on the strategies adopted for participation, stakeholders can be involved to a more or less extensive level in creativity, analysis and synthesis activities.

Table 5. Tools for sustainable design processes

\begin{tabular}{|c|c|c|}
\hline Creativity & Analysis & Synthesis \\
\hline $\begin{array}{l}\text { Backcasting } \\
\text { Biomimicry } \\
\text { Eco-design strategies } \\
\text { Ecological engineering } \\
\text { Factor X engineering } \\
\text { Industrial ecology }\end{array}$ & $\begin{array}{l}\text { Environmental } \\
\text { Ecological footprinting } \\
\text { Emergy }^{\mathrm{a}} \text { or exergy } \mathrm{b}^{\mathrm{a}} \text { alysis } \\
\text { Environmental impact assessment } \\
\text { Environmental life cycle assessment } \\
\text { Strategic environmental assessment } \\
\text { Economic } \\
\text { Cost-benefit analysis } \\
\text { Economic impact analysis } \\
\text { Environmental valuation } \\
\text { Inequality and equity analysis } \\
\text { Life cycle costing } \\
\text { Social } \\
\text { Social impact assessment } \\
\text { Social life cycle assessment } \\
\text { Multidimensional } \\
\text { Generic criteria or indicators lists } \\
\text { Integrated impact assessment } \\
\text { Question grids }\end{array}$ & $\begin{array}{l}\text { Multi-criteria decision aid methods } \\
\text { (Azapagic and Perdan 2005b): } \\
\text { Elementary } \\
\text { Disjunctive and conjunctive } \\
\text { methods } \\
\text { Lexicographic method } \\
\text { Maximin method } \\
\text { Value and utility based } \\
\text { Weighted sum } \\
\text { AHP (Analytic hierarchy } \\
\text { procedure) } \\
\text { SMART (Simple multi-attribute } \\
\text { rating technique) } \\
\text { TOPSIS (Technique for order by } \\
\text { similarity to ideal situation) } \\
\text { Outranking } \\
\text { ELECTRE } \\
\text { PROMETHEE }\end{array}$ \\
\hline
\end{tabular}

${ }^{a}$ Emergy or embodied energy (Odum 1996) "is the available energy [...] used up directly and indirectly to make a service of product."

${ }^{b}$ Exergy (Szargut 2005) "expresses the amount of mechanical work necessary to produce a material in its specified state from components common in the natural environment $[\ldots]$."

Sustainable projects need to be as technically sound as conventional projects. Sustainability tools must thus be used in conjunction with existing approaches associated with state-of-the-art engineering practice.

\section{Proposition of a sustainable design process}

The IESDP builds upon the SDPs in Tables 3 and 4, but also incorporates additional modifications that appear necessary in the light of three key issues emerging from the field of sustainability science. 
Firstly, Lundqvist (2000) pointed out that sustainability criteria and indicators are most of the time chosen in an ad hoc manner, while their selection should instead be based on a causal chain describing the relations between a given project, the related economic activities, the state of the environment and social interactions. The sustainability conceptual framework in Gagnon et al. (2009), presented as a condensed form in Figure 2, was developed to support design teams in the identification of the numerous interrelations existing between an engineering project, the environment, individuals as well as the economy and other social systems.

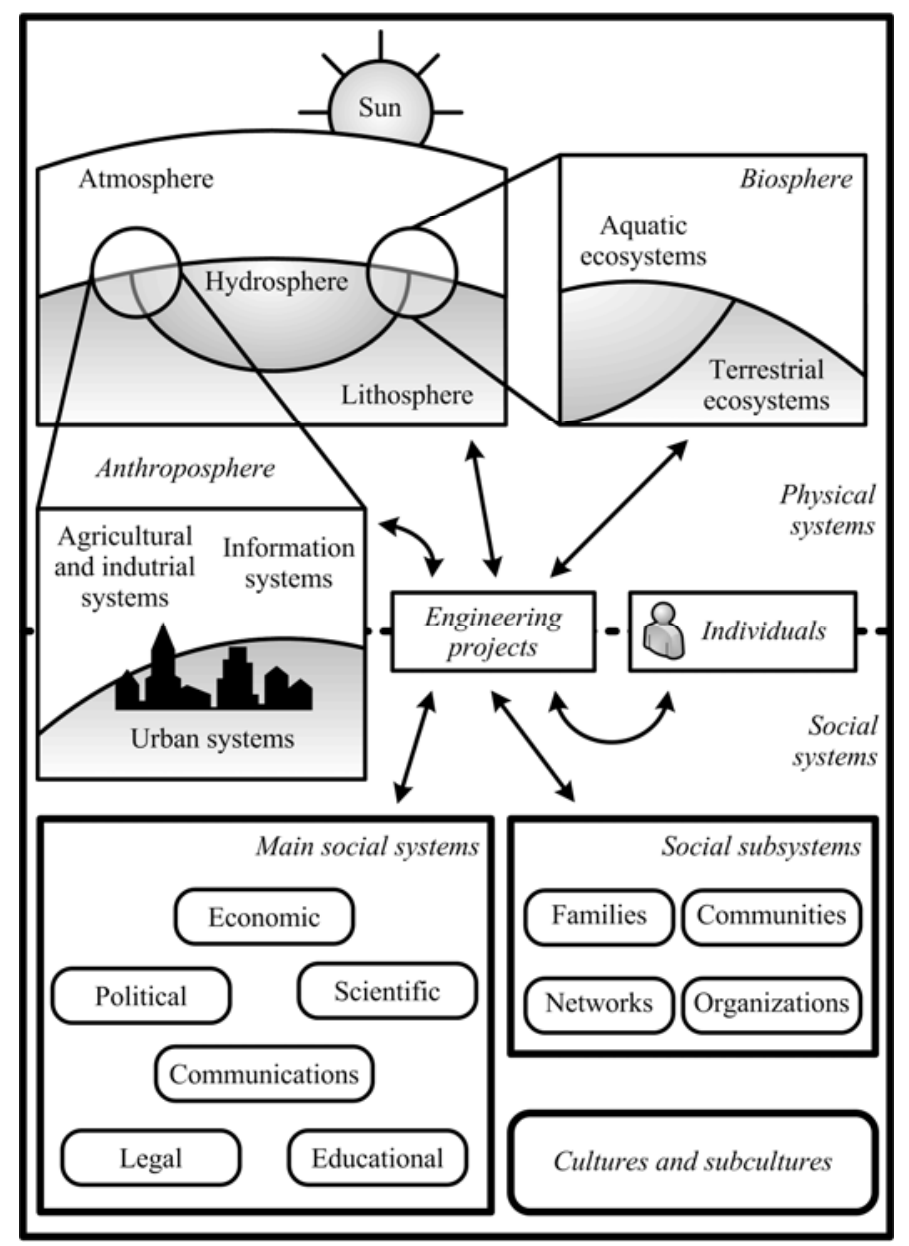

Figure 2. Sustainability conceptual framework, adapted from Gagnon et al. (2009) 
All potential interactions between a project and its global environment cannot be characterized during design because of time and resource constraints. Hence, the conceptual framework (in conjunction with experience from previous projects, scientific and technical literature, as well as stakeholder consultation) can help discern the most important interactions and expose their choice in a transparent manner. The relationships selected will, in turn, be assessed by the design team using appropriate criteria and analysis tools. An overview of potential relationships existing between an engineering project and its global environment is given in Table 6. The list of relationships given is neither exhaustive nor complete. It is rather provided to illustrate the nature of the interactions between projects and the main components of the conceptual framework.

Table 6. Typical relationships between engineering projects and their global environment

\begin{tabular}{|c|c|}
\hline Framework component & Typical relationships \\
\hline $\begin{array}{l}\text { Atmosphere, hydrosphere } \\
\text { and lithosphere }\end{array}$ & Extraction of abiotic resources. Emission of pollutants to air, water and soil. \\
\hline $\begin{array}{l}\text { Aquatic and terrestrial } \\
\text { ecosystems }\end{array}$ & $\begin{array}{l}\text { Extraction of biotic resources. Physical intervention leading to habitat destruction } \\
\text { and biodiversity loss. Effects of ecotoxic pollutants on living organisms. }\end{array}$ \\
\hline Individuals & $\begin{array}{l}\text { Increase in quality of life for consumers or users. Job opportunities and related } \\
\text { working conditions. Contribution to professional or skills development. }\end{array}$ \\
\hline $\begin{array}{l}\text { Agricultural and industrial } \\
\text { systems }\end{array}$ & $\begin{array}{l}\text { Selection of materials, fuels, components, equipments, etc. among those available in } \\
\text { function of their respective characteristics. }\end{array}$ \\
\hline $\begin{array}{l}\text { Urban and information } \\
\text { systems }\end{array}$ & $\begin{array}{l}\text { Compatibility with current configurations of urban systems (infrastructure, land use, } \\
\text { etc.) or information systems (type of data acquired and its availability). }\end{array}$ \\
\hline Economic system & Availability of resources (labour, materials, etc.) and their relative costs. \\
\hline Political system & $\begin{array}{l}\text { Contribution to plans setting particular targets and eligibility to programs providing } \\
\text { fiscal advantages or subsidies. }\end{array}$ \\
\hline Scientific system & $\begin{array}{l}\text { Validation through research projects proving the feasibility of technologies and } \\
\text { setting the grounds for their use in engineering projects. }\end{array}$ \\
\hline Communications system & $\begin{array}{l}\text { Capacity to reach potential stakeholders and interest of stakeholders towards the } \\
\text { information relating to the project. Type of coverage done by media and their } \\
\text { influence on the perceptions of individuals. }\end{array}$ \\
\hline Legal system & $\begin{array}{l}\text { Respect of regulations, codes, standards, etc. and interactions with organizations } \\
\text { responsible for their enforcement. }\end{array}$ \\
\hline Educational system & Competences of engineering and other professionals involved in the project. \\
\hline $\begin{array}{l}\text { Families, communities, } \\
\text { networks and organizations }\end{array}$ & $\begin{array}{l}\text { Acceptability of a project in a given group and evolution of positions following } \\
\text { debates or exchanges. }\end{array}$ \\
\hline Cultures and subcultures & $\begin{array}{l}\text { Compatibility with the current way of living and dominant values or traditions. } \\
\text { Capacity to mobilize people eager for change which share a progressive subculture } \\
\text { or ability to convince people resistant to change which share a conservative } \\
\text { subculture. }\end{array}$ \\
\hline
\end{tabular}


The main benefit resulting from the use of a detailed sustainability conceptual framework is the identification of potential relationships in an exhaustive manner, when compared to a simpler categorization of issues along the typical economic, environmental and social dimensions.

Secondly, the magnitude of change which will affect environmental and social systems during the next decades is only predictable to a limited extent. This is illustrated by the wide range of socio-economic scenarios generated by the Intergovernmental Panel on Climate Change (Nakicenovic and Swart 2000) and the Global Environment Outlook team (Rothman et al. 2007), respectively for the 2000-2100 and 2000-2050 periods. Sustainable solutions thus need to be flexible, in order to be implemented under a large array of circumstances, as well as adaptable, so that required modifications can easily be performed. Hence, the assessment of alternative concepts in sustainable design must consider broad scenarios which reflect potential changes in environmental systems (e.g. effects of climate change on temperature or precipitations), society (e.g. adoption of new regulations or demographic changes), economy (e.g. prices of raw materials, goods and services) and individuals (e.g. changes in behaviour, attitudes or welfare).

Thirdly, solutions which meet the ambitious challenges imposed by sustainability are likely to be radically different from conventional solutions. The required levels of increase in efficiency or decrease in environmental impact from truly sustainable engineering projects are expected to be very high, when compared to conventional projects (Weaver et al. 2000). For example, the European Commission (2009) calls for an $80 \%$ to $95 \%$ decrease in greenhouse gases (GHG) emissions for industrialized countries in 2050 when compared to 1990 levels. In a similar order of magnitude, Schmidt-Bleek (1994) proposed a factor 10 decrease in material inputs per unit of service (MIPS) for western style economies. Moreover, private and public firms now face a whole new realm of demands from multiple stakeholders associated with corporate social responsibility (CSR) (e.g. human rights, labour practices, community involvement and development) (ISO 2009). 
While existing SDPs focus on analysis and synthesis tools, it is also necessary to increase the importance of creativity tools, mostly because incremental innovation is unlikely to provide the level of performance expected from sustainable solutions. For instance, Crul and Diehl (2006) estimate the eco-efficiency improvements associated with incremental innovation to be limited to a factor 2 to 4, while radical innovation is needed to provide factor 10 to 20 gains in efficiency.

Table 7 presents the modifications deemed necessary to move from conventional towards sustainable design. We first identified and adapted the main tasks already proposed in existing SDPs (Tables 3 and 4), as shown by the letters in brackets. This analysis resulted in the definition of 13 tasks, which are mentioned in at least two reviewed SDPs and are consistent with the structure of the generic CDP in Table 2. In a second step, we derived eight other tasks to address the emerging issues in the field of sustainability discussed previously in this section. These complementary tasks are identified with an asterisk.

Of the 21 tasks in Table 7, 11 are in bold because they are identified as critical to achieve completeness of any design process dealing with sustainability. Nine of these tasks were inspired from existing SDPs, considering they were mentioned in as least three sources and thus showed a high level of consensus. We also consider two of the new tasks described in Table 7 to be critical complements. Their choice is based on their strong relationship with the emerging issues discussed, as well as their compatibility with the nine key tasks inspired from existing SDPs. 
Table 7. Integrated sustainable engineering design process (letters in brackets refer to Tables 3 and 4)

\begin{tabular}{|c|c|}
\hline Design phase & Tasks proposed in the reviewed SDPs and complementary tasks proposed \\
\hline $\begin{array}{l}\text { I-Planning and } \\
\text { problem } \\
\text { definition }\end{array}$ & $\begin{array}{l}\text { 1- Form a multidisciplinary design team [B,D,E,H] } \\
\text { 2- Define sustainability principles [A,B,F] } \\
\text { 3- Define a sustainability conceptual framework* } \\
\text { 4- Identify sustainability issues associated with the defined problem [A,B,D,F,G,H] } \\
\text { 5- Identify the relationships between the project and the elements in the conceptual framework* } \\
\text { 6- Analyze stakeholders and plan stakeholder involvement [G,H] }\end{array}$ \\
\hline $\begin{array}{l}\text { II-Conceptual } \\
\text { analysis }\end{array}$ & $\begin{array}{l}\text { 7- Define sustainability criteria in line with the sustainability issues previously identified, } \\
\text { in parallel with technical functions [B,C,D,E,H] } \\
\text { 8- Confirm the comprehensiveness of the sustainability criteria with the conceptual framework* } \\
\text { 9- Develop a vision for the future in which functions are fulfilled respecting the sustainability } \\
\text { principles [A,F] } \\
\text { 10-Generate at least one alternative concept radically different from conventional ones } \\
\text { using sustainability creativity tools* } \\
\text { 11-Define broad scenarios in which the alternative concepts are likely to evolve* } \\
\text { 12-Define sustainability indicators derived from the issues or criteria, in parallel with } \\
\text { technical specifications derived from functions [C,E,G] } \\
\text { 13-Identify the analysis tools with which data will be generated for each of indicators* } \\
\text { 14-Chose a multi-criteria decision aid method [B,E,G] }\end{array}$ \\
\hline $\begin{array}{l}\text { III-Preliminary } \\
\text { design }\end{array}$ & $\begin{array}{l}\text { 15- Assess the performance of alternative concepts according to the sustainability criteria or } \\
\text { indicators [A,D,E,F,G,H], including one "benchmark alternative" representative of } \\
\text { current practice }[\mathrm{B}, \mathrm{D}] \\
\text { 16-Validate the multi-criteria decision aid method chosen and use it to recommend a } \\
\text { preferred concept [B,E,G] } \\
\text { 17-Validate the performance of the alternative concepts under the scenarios identified* }\end{array}$ \\
\hline $\begin{array}{l}\text { IV-Detailed } \\
\text { design }\end{array}$ & $\begin{array}{l}\text { 18-Refine the assessment of the preferred concept [D,C,F] and optimize its performance along } \\
\text { sustainability criteria or indicators [D,C] } \\
\text { 19-Maximize the adaptability of the preferred concept under scenarios identified* } \\
\text { 20-Communicate recommendations for the manufacturing, construction, use and end of life } \\
\text { phases [B,D,H] } \\
\text { 21-Generate the set of sustainability indicators for monitoring [D,E,H] }\end{array}$ \\
\hline
\end{tabular}

Note: The letter in brackets refers to Tables 3 and 4 for a task inspired from existing SDPs, An asterisk refers to a complementary task. Critical tasks are in bold.

Reviewed SDPs stress the importance of life cycle thinking, which main objectives are (UNEP 2007) "to reduce a product's resource use and emissions to the environment as well as improve its socio-economic performance throughout its life cycle, [from cradle to grave]." The design phases of the ISEDP are positioned according to the life cycle stages of a project in Figure 3. 


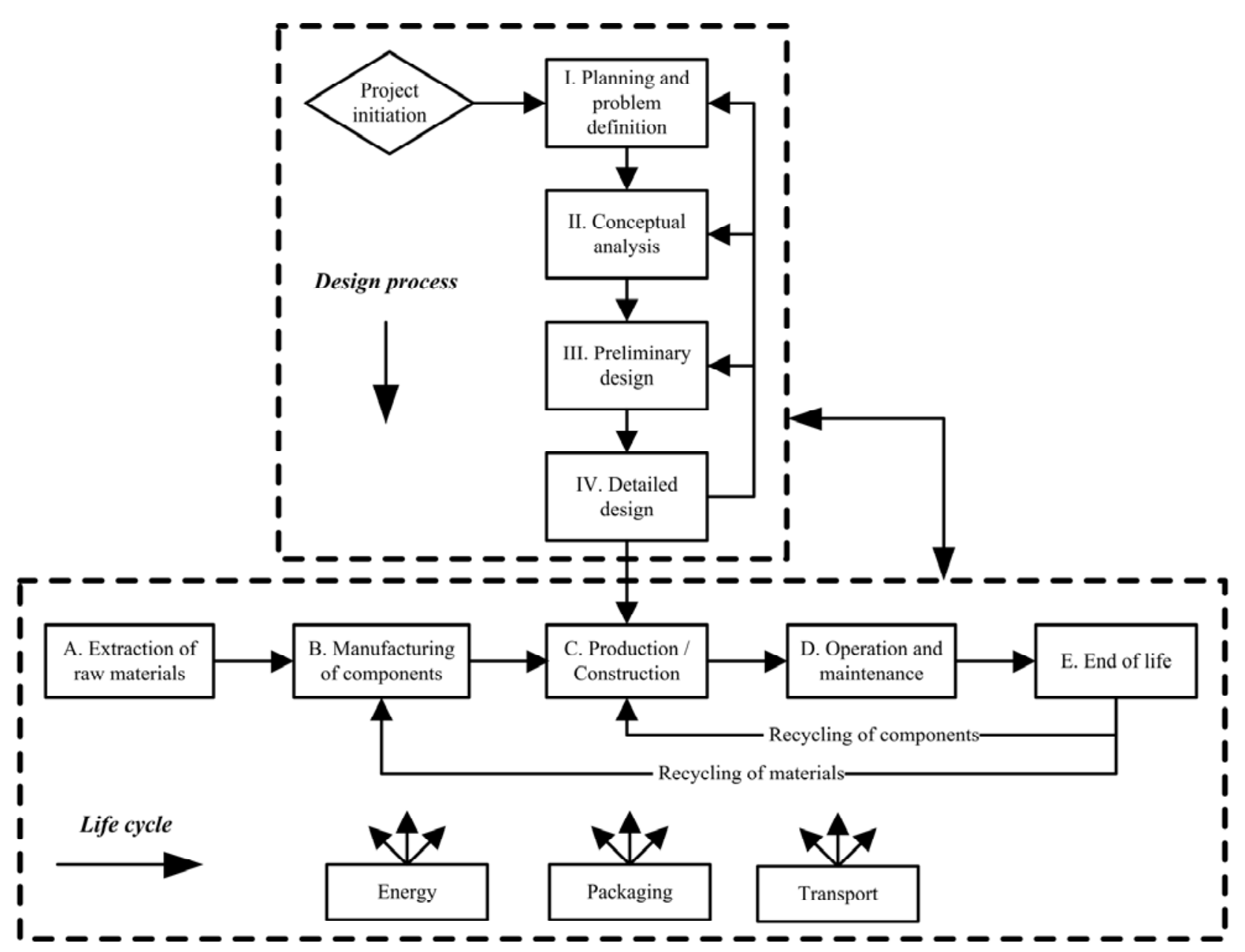

Figure 3. Design phases and life cycle stages, inspired from Brent (2005)

Every project is part of an organizational background consisting of design processes undertaken previously or subsequently. It is also part of a technological background, made of the life cycles of components necessary for the project at stake or more complex assemblies in which this project is included. Many interactions exist between the project at the foreground and its organizational or technological background. For example:

- Life cycle assessments done in previous projects can serve as benchmarks for subsequent projects.

- Solutions implemented in prior projects similar to the one being realized are likely to be part of the considered alternatives. 
- The influence that components provided by external partners have on a project's life cycle is more easily taken into account if their own life cycle attributes are known.

- The expertise in life cycle assessment in an organization increases with a more widespread application of the tool.

Decision making is a delicate matter in all design processes, be they conventional or sustainable. The consideration of a great variety of sustainability issues, in complement with conventional technical issues, poses a problem due to the potentially large number of associated criteria. Azapagic and Perdan (2005a) indicate that most MCDA studies recommend that a maximum of 10 criteria be considered, in order to simplify assessment and decision making. In contrast, sustainability assessment frameworks proposed recently for various engineering applications usually prescribe 10 or more criteria or indicators (not counting technical specifications) as shown by the numbers in brackets: Ashley et al. (2004) [13]; FIDIC (2004) [45]; Palme et al. (2005) [12]; Sahely et al. (2005) [14]; Hung et al. (2007) [11]; Feyzioglu et al. (2008) [7]; Khan (2008) [16]; and Dihn et al. (2009) [10].

To address this problem, criteria can be considered in a sequential manner, reducing the number of them to be treated simultaneously. In order for the potentially large number of sustainability indicators and technical specifications to be considered in an optimal and transparent manner, we propose in Table 8 four categories in which most criteria can be classified. This classification builds on decision rules proposed in existing MCDA methods (Azapagic and Perdan 2005b) as well as common approaches to sustainable design (e.g. LEED certification) (USGBC 2005).

The classification of criteria during the design process according to the categories described in Table 8 has four main advantages:

- Instead of choosing a single MCDA method to handle all potential criteria, they can be considered in the most relevant way along all design phases. 
- The assessment of criteria is usually more precise, and thus more demanding, as we move from the first category to the fourth. Nevertheless, all types of criteria can serve to improve the considered alternatives or influence decision-making. Hence, the use of these categories makes it easier to recognize all criteria guiding design, even the ones not integrated in a weighted MCDA method.

- The structure of the decision-making process can be more clearly presented.

- The extent of the efforts made to move towards sustainable design is more easily evaluated.

Table 8. Categories of criteria considered in the ISEDP

\begin{tabular}{|l|l|l|}
\hline Category & Purpose & Description \\
\hline $\begin{array}{l}\text { Mandatory, non- } \\
\text { discriminating }\end{array}$ & $\begin{array}{l}\text { Screening of } \\
\text { concepts } \\
\text { (conventional } \\
\text { design) }\end{array}$ & $\begin{array}{l}\text { These criteria are associated with regulations, codes, standards, etc. and } \\
\text { relate to various dimensions of sustainability (environmental standards, } \\
\text { health and safety requirements, purchase of regional labour and materials, } \\
\text { etc.) or technical issues. The respect of such criteria is mandatory in } \\
\text { conventional as well as in sustainable design, so they cannot serve to } \\
\text { discriminate the former from the latter. }\end{array}$ \\
\hline $\begin{array}{l}\text { Relative, non- } \\
\text { discriminating }\end{array}$ & $\begin{array}{l}\text { Improvement of } \\
\text { concepts }\end{array}$ & $\begin{array}{l}\text { This category of criteria guides the improvement of a given concept and } \\
\text { serves to assess, in a qualitative or quantitative manner, the relative } \\
\text { improvement realized compared to an initial configuration. These criteria } \\
\text { thus help making each alternative concept more sustainable, but do not } \\
\text { allow comparison between the concepts. }\end{array}$ \\
\hline $\begin{array}{l}\text { Threshold, } \\
\text { discriminating }\end{array}$ & $\begin{array}{l}\text { Screening of } \\
\text { concepts }\end{array}$ & $\begin{array}{l}\text { Threshold criteria set objectives (more demanding than mandatory } \\
\text { requirements) that concepts need to respect in order to be considered } \\
\text { acceptable (go/no-go testing). Concepts which meet the criteria can pass on } \\
\text { to subsequent design phases (go) and are discriminated from those who } \\
\text { cannot (no-go). }\end{array}$ \\
\hline $\begin{array}{l}\text { Weighted, } \\
\text { discriminating }\end{array}$ & $\begin{array}{l}\text { Identification of } \\
\text { an optimal } \\
\text { concept }\end{array}$ & $\begin{array}{l}\text { These criteria are considered in a single decision step, with the help of one } \\
\text { of the many weighted MCDA methods available (Table 5). An optimal } \\
\text { concept outperforming others is identified, the outcome depending on the } \\
\text { criteria considered and the decision rules particular to the chosen MCDA } \\
\text { method. }\end{array}$ \\
\hline
\end{tabular}

In the next section, we present how the use of these different types of criteria, in conjunction with variations along five other dimensions, makes it possible to differentiate shades of sustainability existing in engineering design.

\section{Shades of sustainability for engineering design}

Sustainable design is often described in opposition to conventional design. The integration of relevant sustainability issues, the use of sustainability assessment tools and the consideration of a range of 
sustainability criteria for decision-making should allow an engineer to implement sustainable design and thus choose the most sustainable option among those considered. On the other hand, sustainable engineering is presented as an ideal to achieve, an ideal we are now just starting to envision and formalize (FIDIC 2004). In that perspective, it is not only sufficient to settle upon the most sustainable solution amongst those available for a given project. It is also fundamental to determine if the preferred option is sustainable enough and if not, aim for more ambitious objectives in projects undertaken subsequently. Positioning conventional and sustainable design on a continuum emphasizes the fact that an engineer or an organization gradually moves from the former approach to the latter. In this perspective, it is possible to evaluate the progress accomplished as more and more projects integrate sustainability objectives. In this section, we set the foundations of a procedure which aims to reveal the different shades of sustainability existing in engineering design.

The method presented here includes four shades of sustainability (from $A$ to $D$ ), $A$ being the lightest shade (i.e. most elementary) and $D$ the deepest (i.e. most advanced). Based on the 11 key tasks of the ISEDP described in Table 7, conventional design is differentiated from sustainable design along six specific dimensions: (1) the structure of the design process, (2) the range of sustainability issues considered, (3) the relevance of the indicators guiding design, (4) the accuracy of the tools used to evaluate indicators, (5) the potential improvements expected from the alternatives assessed when compared to conventional solutions and (6) the approach to decision making. Table 9 provides an overview of the six dimensions and their assessment along the four shades is illustrated by examples. A more detailed description for each dimension follows. 
Table 9. Dimensions and shades of sustainability for engineering design

\begin{tabular}{|c|c|c|c|c|c|}
\hline \multirow{2}{*}{\multicolumn{2}{|c|}{ Dimensions }} & \multicolumn{4}{|c|}{ Shades of sustainability } \\
\hline & & A & $\mathrm{B}$ & $\mathrm{C}$ & $\mathrm{D}$ \\
\hline \multirow{2}{*}{$\begin{array}{l}\text { 1. Design } \\
\text { process }\end{array}$} & Was the SDP implemented? & Minimally & Partially & Mostly & Entirely \\
\hline & $\begin{array}{l}\text { Example: Number of tasks of the } \\
\text { ISEDP completed (Table 7). }\end{array}$ & 11 key tasks in bold & $\begin{array}{l}\text { 12-15 tasks, including } \\
\text { key tasks }\end{array}$ & $\begin{array}{l}16-19 \text { tasks, including } \\
\text { key tasks }\end{array}$ & $\begin{array}{l}20-21 \text { tasks, including } \\
\text { key tasks }\end{array}$ \\
\hline \multirow{2}{*}{$\begin{array}{l}\text { 2. Sustainability } \\
\text { issues covered }\end{array}$} & $\begin{array}{l}\text { Are sustainability issues considered in } \\
\text { design through criteria and indicators? }\end{array}$ & $\begin{array}{l}\text { Low number of } \\
\text { unbalanced issues }\end{array}$ & $\begin{array}{l}\text { Low number of } \\
\text { balanced issues }\end{array}$ & $\begin{array}{l}\text { Acceptable number of } \\
\text { balanced issues }\end{array}$ & $\begin{array}{l}\text { High number of } \\
\text { balanced issues }\end{array}$ \\
\hline & $\begin{array}{l}\text { Example: Number of sustainability } \\
\text { issues covered by criteria and } \\
\text { indicators. }\end{array}$ & $\begin{array}{l}\text { 4-6 issues, mostly } \\
\text { covering a single SD } \\
\text { pillar }\end{array}$ & $\begin{array}{l}\text { 4-6 issues, covering } \\
\text { all SD pillars }\end{array}$ & $\begin{array}{l}\text { 7-10 issues, covering } \\
\text { all SD pillars }\end{array}$ & $\begin{array}{l}\text { More than } 10 \text { issues, } \\
\text { covering all SD pillars }\end{array}$ \\
\hline \multirow[b]{2}{*}{$\begin{array}{l}\text { 3. Relevance of } \\
\text { the indicators }\end{array}$} & $\begin{array}{l}\text { Are the indicators chosen relevant to } \\
\text { the associated issues? }\end{array}$ & $\begin{array}{l}\text { Indicator chosen with } \\
\text { a partial relation to a } \\
\text { group of issues }\end{array}$ & $\begin{array}{l}\text { Indicator with a partial } \\
\text { relation to a single } \\
\text { issue }\end{array}$ & $\begin{array}{l}\text { Indicator with a strong } \\
\text { relation to a single } \\
\text { issue }\end{array}$ & $\begin{array}{l}\text { Indicator entirely } \\
\text { covering a single issue }\end{array}$ \\
\hline & $\begin{array}{l}\text { Example: Indicators related to } \\
\text { environmental issues such as climate } \\
\text { change and resource use. }\end{array}$ & $\begin{array}{l}\text { Energy use during } \\
\text { operation phase to } \\
\text { assess contribution to } \\
\text { climate change and } \\
\text { resource use }\end{array}$ & $\begin{array}{l}\text { Energy use during } \\
\text { operation to assess } \\
\text { contribution to climate } \\
\text { change }\end{array}$ & $\begin{array}{l}\text { Carbon dioxide } \\
\text { emissions to assess } \\
\text { contribution to climate } \\
\text { change }\end{array}$ & $\begin{array}{l}\text { Aggregated } \\
\text { greenhouse gas } \\
\text { emissions to assess } \\
\text { contribution to climate } \\
\text { change }\end{array}$ \\
\hline \multirow{2}{*}{$\begin{array}{l}\text { 4. Accuracy of } \\
\text { the analysis } \\
\text { tools }\end{array}$} & $\begin{array}{l}\text { Are the chosen tools accurate to assess } \\
\text { the chosen indicators? }\end{array}$ & Minimally & Moderately & Highly & State-of-the-art \\
\hline & $\begin{array}{l}\text { Example: Evaluation of life cycle } \\
\text { environmental impacts. }\end{array}$ & Streamlined LCA & $\begin{array}{l}\text { Economic input- } \\
\text { output LCA }\end{array}$ & $\begin{array}{l}\text { Process LCA, mostly } \\
\text { with secondary data }\end{array}$ & $\begin{array}{l}\text { Process LCA mostly } \\
\text { with primary data }\end{array}$ \\
\hline \multirow[t]{2}{*}{$\begin{array}{l}\text { 5. Performance } \\
\text { of alternatives }\end{array}$} & $\begin{array}{l}\text { What is the level of improvement when } \\
\text { compared to a benchmark solution or } \\
\text { the amount of progress towards an } \\
\text { ideal solution? }\end{array}$ & Minimal & Fair & High & Ideal \\
\hline & $\begin{array}{l}\text { Example: Reduction in environmental } \\
\text { impact compared with benchmark. }\end{array}$ & Factor $1,5-2$ & Factor 2-4 & Factor $4-10$ & Factor $10-50$ \\
\hline \multirow[b]{2}{*}{$\begin{array}{l}\text { 6. Decision } \\
\text { making }\end{array}$} & $\begin{array}{l}\text { Were criteria covering all dimensions } \\
\text { of sustainability considered in a } \\
\text { balanced manner? }\end{array}$ & Minimally & Partially & Mostly & Entirely \\
\hline & $\begin{array}{l}\text { Example: Number of criteria for each } \\
\text { pillar of sustainable development (SD) } \\
\text { corresponding to the categories } \\
\text { described in Table } 8 \text {. }\end{array}$ & $\begin{array}{l}\text { Most criteria are } \\
\text { "relative, non- } \\
\text { discriminating", with } \\
\text { cost issues } \\
\text { predominating }\end{array}$ & $\begin{array}{l}\text { Most criteria are } \\
\text { "threshold, } \\
\text { discriminating", with } \\
\text { cost issues } \\
\text { predominating }\end{array}$ & $\begin{array}{l}\text { Most criteria are } \\
\text { "threshold" or } \\
\text { "weighted, } \\
\text { discriminating", with } \\
\text { most weight given to } \\
\text { one or two SD pillars }\end{array}$ & $\begin{array}{l}\text { Most criteria are } \\
\text { "threshold" or } \\
\text { "weighted, } \\
\text { discriminating”, with } \\
\text { similar weight given } \\
\text { to all SD pillars }\end{array}$ \\
\hline
\end{tabular}


The first dimension relates to the structure of the process followed by the design team. Its assessment is based on the number of tasks composing the ISEDP, as detailed in Table 9. The design process selected does not necessarily need to be identical to the ISEDP proposed in this paper. It should nevertheless include tasks similar to 11 key ones identified in Table 7. Obviously, carrying out all the tasks composing a SDP does not guarantee a project will be more sustainable than its conventional counterparts once implemented. However, we believe that sustainable solutions are more likely to be adopted if the broad number of related issues and strategies are dealt with in a structured manner.

The second dimension concerns the range of sustainability issues considered during the design process through their associated criteria and indicators. As detailed in Table 9, the number of issues considered is an important factor, as is the coverage of issues pertaining to all pillars of sustainable development (e.g. economic, environmental and social). The number of issues characterizing each shade is based on the sustainability assessment frameworks cited in the previous section, which suggest between 7 and 45 criteria or indicators (for an average of 16) to provide a comprehensive coverage. These numbers are given as an indicative basis and can change from one project to another, depending on their nature and complexity.

The third dimension is linked to the preceding one, as it depends on the level of adequacy existing between the identified sustainability issues and their associated indicators. As explained in Table 9, the closer an indicator is related to the issue assessed, the higher it is positioned in the shades of sustainability. An example concerning environmental impact is given in Table 9 to illustrate the application of this dimension. Like all lists of sustainability indicators, those guiding design should have the following characteristics: value relevance, understandability, measurability, non-redundancy, judgemental independence, balance between completeness and conciseness, and operationality (Azapagic and Perdan 2005a). 
Contrary to the first two dimensions, for which the shade is defined for the whole design process, the third dimension is evaluated on an issue-by-issue basis, since the adequacy between issues and their associated indicators is likely to vary. Once the shade for each issue is defined, the overall performance for the third dimension can be deduced from individual performances. At first, every issue can be attributed an equal importance in order to simplify calculations. More complex approaches can be considered if particular issues appear to dominate during subsequent phases of design.

The fourth dimension is closely linked to the third, as it serves to characterize the accuracy of the analysis tools chosen to assess the indicators previously defined. Table 9 illustrates how the shade for this dimension can be defined in the case of different life cycle assessment methods providing increasingly accurate results. The way each shade is defined along the fourth dimension is likely to change in time, as more accurate tools are developed and state-of-the-art practices evolve with experience being acquired in the different fields of sustainability science. Similar to the third dimension, the shade of a project for this dimension is evaluated on an indicator-by-indicator basis, the overall performance being derived from individual scores.

The fifth dimension pertains to the performance of the considered alternatives along the chosen sustainability indicators and aims to highlight the potential level of improvement provided by these options. It provides the design team feedback on the alternatives generated by evaluating how close (or far) each one of them is from an ideal sustainable solution. An example related to the evaluation of environmental impacts is given in Table 9. This dimension is also assessed on an indicator-by-indicator basis, thus complicating the calculation of an overall performance. Two distinct approaches are conceivable, each corresponding to a different perspective based on the type of information sought. On the one hand, it can be considered useful to identify how each option globally compares to the ideal solution. An aggregate score can thus be calculated for every option based on their performance on each indicator. In that case, the shade for the fifth dimension would correspond to the overall shade of the best performing 
option. On the other hand, the design team might want to know if the strengths of each option, when combined, could provide an ideal solution. An aggregate score would again be calculated, this time based on the best performance among all options for each indicator.

An intermediate approach can also be chosen, based on the score of the best option for each of the three main pillars of sustainability. For example, two alternatives could have the following overall profiles along environmental, social and economic criteria: $B-C-A$ for option 1 and $C-A-B$ for option 2 . The combined performance along which the shade could be defined is in that case $C-C$ - $B$. Such a result suggests that each alternative holds a relatively high potential for improvement for at least one dimension and that an option combining the best aspects of both alternatives should be considered in a subsequent project.

The sixth and last dimension included in the procedure concerns the decision making process leading to the choice of the concept to be implemented. This dimension refers to the types of criteria considered during decision making, as defined in Table 8. As illustrated in Table 9, the more dimensions of sustainable development are taken into account in a balanced way (i.e. are given similar importance), the deepest is the shade. This is based on the fact that sustainable engineering strives to develop solutions with a high level of performance along all three sustainability pillars simultaneously.

\section{Discussion}

We will now provide an overview of how the various dimensions of sustainable design relate one to another. The following remarks emphasize how a low score for a given dimension cannot be entirely compensated by good performances according to other dimensions. This, in turn, affects the potential applications of the procedure, as detailed later in the discussion. 
First, it is possible for a design process to score reasonably well on most dimensions, except the fifth one concerning the relative performance of alternatives. In this situation, sustainability issues would have been well defined and options well assessed. Nevertheless, if truly sustainable solutions are sought, this cannot fully compensate the fact that the alternatives considered were not different enough from conventional solutions. Such an outcome points out to a lack of creativity and indicates that the design team has to consider more diverse or radical options in future projects.

Second, a good result on the fifth and sixth dimensions combined with relatively low scores for most preceding dimensions raises doubts on the soundness of conclusions drawn during design. Key sustainability issues might have been ignored, giving only a partial picture of the project, or solutions might have been assessed in an imprecise manner, limiting the possibilities to discriminate one option from another. The design team would need to explain these limitations when the final design is communicated to clients or stakeholders.

The third situation is the opposite of the one just above, whereas low scores on the fifth and sixth dimensions coincide with a good performance for all other dimensions. This would indicate that efforts made to well circumscribe the problem at stake did not materialize into tangible results. Nevertheless, an engineer or an organization is likely to benefit, in subsequent projects, from this capacity to generate and assess solutions in a sustainable manner.

The multi-dimensional nature of the procedure elaborated inevitably raise questions on compensation or comparability between the dimensions of sustainable design. We will now suggest different ways to tackle this issue, depending on the intended application of the procedure.

In the case it is used for auto-evaluation purposes by an organization committed to improve current practices, the procedure will primarily serve to highlight dimensions along which the actual design process 
is least satisfying (i.e. identification of weak links). For this application, the calculation of a single score or the definition of an index is not necessarily relevant, since improvements along all dimensions, with priority given to the lowest scoring ones, should be targeted.

The procedure can also provide a critical picture of engineering practice, at a given moment and through time, based on the comparative analysis of a selection of projects. In this case, all dimensions can be considered individually and projects compared by the use of radar plots. To simplify the comparison between groups of projects realized at different times, a composite indicator (or aggregate index) might be required. As discussed in OECD (2008), the development of composite indicators is, by itself, a vast and complex subject. Hence, we do not propose a particular aggregation method, but we believe the two following factors should be considered when choosing one:

- The different dimensions of sustainable design relate to different phases in the design process itself. These phases are linked and influence one another, as it is also the case for the various dimensions of sustainable design. Any weighting set should be defined considering that, while each dimension might not be equally important, all play a significant role in sustainable design.

- Progress achieved during a given project must be given credit, even if it concerns only a few dimensions, because the experience gained will be useful in subsequent projects. Nevertheless, weak scores for some dimensions cannot be entirely compensated by strong ones for others. The aggregation method chosen must thus be sensible to these low scores.

The last application, and probably the most sensitive, is the characterization by an organization of its design practices to make public claims about their contribution to sustainable development. The previous discussion concerning aggregation applies if the use of a single indication is desired by the organization. In addition, measures inspired from those in standards for life cycle assessment (ISO 2006) to prevent abusive claims are necessary to ensure the validity and comparability of such declarations (e.g. transparent and detailed reporting, reference to recognized practices, independent external review, etc.). 
It this now common to see projects or products described as being "sustainable". The fact that these claims are not always justified might explain, at least partially, scepticism expressed towards the concept of sustainable development itself. The procedure proposed above addresses this problem by offering professionals and organizations committed to sustainable engineering a comprehensive picture of their current position along the different shades of sustainable design. While acknowledging efforts being made in the present, the procedure also serves as a road-map by setting ambitious objectives for each phase of the design process. In addition, it supports the appropriate use of the term "sustainable development" in the engineering community by offering more critical and lucid insights on the progress made during the last decade as well as on the challenges still facing us.

\section{Conclusions}

In the light of existing sustainable design processes and sustainable decision-making frameworks, it was possible to identify a series of tasks differentiating sustainable from conventional design. Additional modifications were also derived from important issues emerging from the field of sustainability and integrated into the ISEDP. With sustainable design well delineated and related applications more common, a method was elaborated to evaluate the extent of the progress made towards sustainable engineering as well as the additional efforts needed in the next decades. This method sets out four shades along six dimensions for which sustainable design contrasts with its conventional counterpart. The expected results and potential applications discussed show that the procedure is comprehensive and flexible enough for engineers or organizations to build upon it in case studies. Moreover, it will allow them to advance in a structured manner towards the integration of sustainability issues into design activities. Finally, future case studies implementing the method will help refine the way shades of sustainable design are interpreted and illustrate more clearly its usefulness. 


\section{Acknowledgments}

The authors thank the National Science and Engineering Research Council of Canada (NSERC), the Fonds québécois de la recherche sur la nature et les technologies (FQRNT) and the Fonds québécois de recherche sur la société et la culture (FQRSC) for their financial support.

\section{References}

Ashley, R., Blackwood, D., Butler, D. and Jowitt, P. (2004). Sustainable water services: a procedural guide. IWA Publishing, London .

Ashley, R., Blackwood, D., Butler, D., Jowitt, P., Davies, J., Smith, H., Gilmour, D. and OlteanDumbrava, C. (2008). "Making asset investment decisions for wastewater systems that include sustainability.” J. Env. Eng., 134(3), 200-209.

Azapagic, A. and Perdan, S. (2005a). “An integrated sustainability decision-support framework - Part I: problem structuring.” Int. J. Sust. Dev. World Ecol., 12(2), 98-111.

Azapagic, A. and Perdan, S. (2005b). "An integrated sustainability decision-support framework - Part II: problem analysis.” Int. J. Sust. Dev. World Ecol., 12(2), 112-131.

Bouchart, F. J.-C., Blackwood, D. J. and Jowitt, P. W. (2002). "Decision mapping: understanding decision making processes.” Civil Eng. And Env. Syst., 19(3), 187-207.

Boyko, C. (2009). “The urban design decision-making process: a new approach.” Designing sustainable cities, Cooper, R., Evans, G. and Boyko, C., eds, John Wiley \& Sons, Chicester, United Kingdom, 42-50.

Brent, A. C. (2005). "The application of life cycle management in decision making for sustainable development at government and corporate level: the integration of project, asset and product life cycles." Prog. Ind. Ecol. Int. J., 2(2), 223-235.

Byggeth, S. H. (2001). "Integration of sustainability aspects in product development.” Ph.D. Thesis, Chalmers University of Technology and Göteborg University, Göteborg, Sweden.

Crul, M. R. M. and Diehl, J. C. (2006). Design for sustainability: a practical approach for developing economies. UNEP, Paris.

Dhillon, B. S. (1996). Engineering design: a modern approach. McGraw-Hill, New York, NY.

Dihn, L. T. T., Guo, Y. and Mannan, M. S. (2009). "Sustainability evaluation of biodiesel production using multicriteria decision-making.” Environ. Prog. Sust. Energ., 28(1), 38-46.

Dym, C. L. and Little, P. (1999). Engineering design: a project-based introduction. John Wiley \& Sons, New York, NY.

Edwards, A. R. (2005). The sustainability revolution: portrait of a paradigm shift. New Society Publishers, Gabriola Island, BC. 
European Commission (2009). "EU action against climate change." $<$ http://ec.europa.eu/environment/climat/pdf/brochures/post 2012 en.pdf> (Jan. 20, 2010).

Feyzioglu, O., Ersoy, M. S. and Buyukozkan, G. (2008). "Multi-criteria selection of alternatives for sustainable urban transportation.” Proc., 2008 Int. Conf. on Industrial Engineering and Engineering Management, IEEE, Piscataway, NJ, 395-399.

International Federation of Consulting Engineers (FIDIC) (2004). Project sustainability management Guidelines. Geneva.

Gagnon, B., Leduc, R. and Savard, L. (2009). "Sustainable development in engineering: a review of principles and definition of a conceptual framework.” Env. Eng. Sci., 26(10), 1459-1472.

Hung, M.-L., Ma, H.-W and Yang, W.-F. (2007). "A novel sustainable decision making model for municipal solid waste management.” Waste Manage., 27(2), 209-219.

International Panel on Climate Change (IPCC) (2007). "Climate change 2007: synthesis report." <http://www.ipcc.ch/pdf/assessment-report/ar4/syr/ar4_syr.pdf> (Nov. 20, 2009).

International Organization for Standardization (ISO) (2002). Environmental management - Integrating environmental aspects into product design and development. ISO/TR 14062:2002, Geneva.

ISO (2006). Environmental management - Life cycle assessment - Principles and framework. ISO 14062:2002, Geneva.

ISO (2009). "Guidance on social responsibility". ISO/DIS 26000, $<$ http://isotc.iso.org/livelink/livelink/fetch/2000/2122/830949/3934883/3935837/ISO DIS 26000_Guidan ce on Social_Responsibility.pdf?nodeid $=8385026 \& v e r n u m=0>(N o v .10,2009)$.

Khan, A. M. (2008). "Sustainability criteria for the evaluation of urban transportation systems." Proc., 2008 Annual Conference, CSCE, Montreal, QC, TR-496.

Lu, B. and Gu, P. (2003). "Systematic life cycle design for sustainable product development.” Proc., 2003 Design Engineering Technical Conf. and Computers and Information in Engineering Conf., ASME, New York, NY, 85-94.

Lundqvist, U. (2000). “On sustainability indicators and sustainable product development.” Ph.D. Thesis. Chalmers University of Technology and Göteborg University, Göteborg, Sweden.

Mosborg, S., Adams, R. Kim, R., Atman, C. J., Turns, J. and Cardella, M. (2005). "Conceptions of the engineering ensign process: an expert study of advanced practicing professionals." Proc., Annual American Society of Engineering Education Conf., Washington, D.C.

Mulder, K. (2006). Sustainable development for engineers. Greenleaf Publishing, Sheffield, England.

Nakicenovic, N. and Swart, R. (2000). Special report on emissions scenarios. Cambridge University Press, Cambridge, United Kingdom.

Ness, B., Urbel-Piirsalu, E., Anderberg, S., Olsson, L. (2007). "Categorising tools for sustainability assessment.” Ecol. Econ., 60(3), 498-508. 
Odum, H.T. (1996). Environmental accounting : emergy and environmental decision making. John Wiley \& Sons, New York, NY.

Organisation for Economic Co-operation and Development (OECD) (2008). Handbook on constructing composite indicators: methodology and user guide. OECD Publications, Paris.

Ordre des ingénieurs du Québec (2003). Guide de pratique professionnelle. Ordre des ingénieurs du Québec, Montreal, QC.

Palme, U., Lundin, M., Tillman, A.-M. and Molander, S. (2005). "Sustainable development indicators for wastewater systems - researchers and indicator users in a co-operative case study.” Resour. Conserv. Recy., 43(3), 293-311.

Robèrt, K.-H., Schmidt-Bleek, B., Aloisi de Larderel, J., Basile, G., Jansen, J. L., Kuerh, R., Price Thomas, P., Suzuki, M., Hawken, P. and Wackernagel, M. (2002). "Strategic sustainable development selection, design and synergies of applied tools.” J. Clean. Prod., 10 (3), 197-214.

Rothman, D. S., Agard, J. and Alcamo, J. (2007). “The future today.” Global environment outlook 4, United Nations Environment Program (UNEP), ed., Paris, 397-454.

Sahely, H. R., Kennedy, C. A. and Adams, B. J. (2005). "Developing sustainability criteria for urban infrastructure systems.” Can. J. Civ. Eng., 32(1), 72-85.

Schmidt-Bleek, F. (1994). How to reach a sustainable economy?. Wuppertal Paper no.24, Wuppertal Institute, Berlin.

Szargut, J. (2005). Exergy method: technical and ecological applications. WIT Press, Southampton, United Kingdom.

The Conference Board of Canada (2009). "Society - Life satisfaction." $<$ http://www.conferenceboard.ca/HCP/Details/society/life-satisfaction.aspx > (Nov. 20, 2009).

UNEP (2007). Life cycle management - A business guide to sustainability. United Nations Environment Program, Paris.

United Nations (UN) (2009). The Millenium Development Goals Report 2009. United Nations Department of Economic and Social Affairs, New York, NY.

US Green Building Council (USGBC) (2005). "LEED for new constructions and major renovations.” http://www.usgbc.org/ShowFile.aspx?DocumentID=1095 (Jan. 20, 2010).

Vié, J.-C., Hilton-Taylor, C. and Stuart, S. N. (2009). Wildlife in a changing world - An analysis of the 2008 IUCN red list of threatened species. IUCN, Gland, Switzerland.

Weaver, P., Jansen, L., van Grootveld, G., van Spiegel, E., Vergragt, P. (2000). Sustainable technology development. Greenleaf Publishing, Sheffield, United Kingdom.

World Commission on Environment and Development (WCED) (1987). Our common future. Oxford University Press, Oxford, United Kingdom. 